\title{
The phenotype of SDHB germline mutation carriers: a nationwide study
}

\author{
Nicolasine D Niemeijer', Johannes A Rijken², Karin Eijkelenkamp³, \\ Anouk N A van der Horst-Schrivers ${ }^{3}$, Michiel N Kerstens ${ }^{3}$, Carli M J Tops ${ }^{4}$, \\ Anouk van Berkel ${ }^{5}$, Henri J L M Timmers ${ }^{5}$, Henricus P M Kunst ${ }^{6}$, C René Leemans ${ }^{2}$, \\ Peter H Bisschop ${ }^{7}$, Koen M A Dreijerink ${ }^{8}$, Marieke F van Dooren ${ }^{9}$, \\ Jean-Pierre Bayley ${ }^{10}$, Alberto M Pereira ${ }^{1}$, Jeroen C Jansen ${ }^{11}$, Frederik J Hes ${ }^{4}$, \\ Erik F Hensen ${ }^{2}$ and Eleonora P M Corssmit ${ }^{1}$
}

\begin{abstract}
${ }^{1}$ Department of Endocrinology and Metabolic Diseases, Leiden University Medical Center, Leiden, the Netherlands, ${ }^{2}$ Department of Otorhinolaryngology/Head and Neck Surgery, VU University Medical Center, Amsterdam, the Netherlands, ${ }^{3}$ Department of Endocrinology, University of Groningen, University Medical Center Groningen, Groningen, the Netherlands, ${ }^{4}$ Department of Clinical Genetics, Leiden University Medical Center, Leiden, the Netherlands, ${ }^{5}$ Division of Endocrinology, Department of Internal Medicine, ${ }^{6}$ Department of Otorhinolaryngology/Head and Neck Surgery, Radboud University Medical Center, Nijmegen, the Netherlands, ${ }^{7}$ Department of Endocrinology and Metabolism, Academic Medical Center, University of Amsterdam, Amsterdam, the Netherlands, ${ }^{8}$ Department of Endocrine Oncology, University Medical Centre Utrecht, Utrecht, the Netherlands, ${ }^{9}$ Department of Clinical Genetics, Erasmus MC, University Medical Center, Rotterdam, the Netherlands, ${ }^{10}$ Department of Human Genetics, and ${ }^{11}$ Department of Otorhinolaryngology, Leiden University Medical Center, Leiden, the Netherlands
\end{abstract}

Correspondence should be addressed to N D Niemeijer Email n.d.niemeijer@lumc.nl

\begin{abstract}
Objective: Succinate dehydrogenase B subunit (SDHB) gene germline mutations predispose to pheochromocytomas, sympathetic paragangliomas, head and neck paragangliomas and non-paraganglionic tumors (e.g. renal cell carcinoma, gastrointestinal stromal tumor and pituitary neoplasia). The aim of this study was to determine phenotypical characteristics of a large Dutch cohort of $S D H B$ germline mutation carriers and assess differences in clinical phenotypes related to specific SDHB mutations.

Design: Retrospective descriptive study.

Methods: Retrospective descriptive study in seven academic centers.

Results: We included 194 SDHB mutation carriers consisting 65 (33.5\%) index patients and $129(66.5 \%)$ relatives. Mean age was $44.8 \pm 16.0$ years. Median duration of follow-up was 2.6 years (range: $0-36)$. Sixty persons (30.9\%) carried the exon 3 deletion and $46(23.7 \%)$ the c. $423+1 \mathrm{G}>\mathrm{A}$ mutation. Fifty-four mutation carriers $(27.8 \%)$ had one or multiple head and neck paragangliomas, $4(2.1 \%)$ had a pheochromocytoma and $26(13.4 \%)$ had one or more sympathetic paragangliomas. Fifteen patients $(7.7 \%)$ developed metastatic paraganglioma and $17(8.8 \%)$ developed non-paraganglionic tumors. At study close, there were 111 (57.2\%) unaffected mutation carriers. Statistical analyses showed no significant differences in the number and location of head and neck paragangliomas, sympathetic paragangliomas or pheochromocytomas, nor in the occurrence of metastatic disease or other tumors between carriers of the two founder $S D H B$ mutations (exon 3 deletion vs c. $423+1 \mathrm{G}>\mathrm{A}$ ).

Conclusions: In this nationwide study of disease-affected and unaffected SDHB mutation carriers, we observed a lower rate of metastatic disease and a relatively high number of head and neck paragangliomas compared with previously reported referral-based cohorts.

European Journal of Endocrinology (2017) 177, 115-125
\end{abstract}

C 2017 European Society of Endocrinology Printed in Great Britain
Published by Bioscientifica Ltd. 


\section{Introduction}

Paragangliomas (PGLs) are rare vascular, neuroendocrine tumors of paraganglia. They derive from either sympathetic chromaffin tissue of the adrenal medulla (also termed pheochromocytoma (PCC)) and extra-adrenal locations (also termed sympathetic PGL (sPGL)) or from parasympathetic tissue of the head and neck (HNPGL) (1). PGLs can occur spontaneously or as part of a hereditary syndrome. Most familial cases of PCC and/or PGL and $10-20 \%$ of sporadic cases carry germline mutations. In the Netherlands, succinate dehydrogenase $(S D H)$ germline mutations are responsible for most hereditary cases. The $S D H A, S D H B, S D H C$ and SDHD genes encode for the four subunits of succinate dehydrogenase (also mitochondrial complex II), a key respiratory enzyme that links the Krebs cycle and the electron transport chain (2). The SDHAF2 gene encodes SDH complex assembly factor 2 (SDHAF2), essential for flavination of the SDHA protein and SDH enzyme activity (3). These various germline mutations have distinct phenotypic effects. SDHD-related PGL/PCCs are usually characterized by multiple PGLs, predominantly located in the head and neck region with a low frequency of malignancy. In contrast, $S D H B$-related disease is often diagnosed as a single tumor (4). Furthermore, $S D H B$ mutation carriers more frequently develop sPGLs, PCCs and metastatic disease than mutation carriers in the other subunits of the $S D H$ gene $(5,6,7)$. Although initial malignancy rates as high as $31-97 \%$ were reported for SDHB-related PGL $(5,6,7,8,9)$, we recently reported risks of metastatic disease in $S D H B$ mutation carriers that were considerably lower. A systematic review and metaanalysis reported by Van Hulsteijn et al. demonstrated that the pooled prevalence of metastatic disease was $13 \%$ in populations including both asymptomatic $S D H B$ mutation carriers and mutation carriers with manifest PGL, and 23\% in studies that included only mutation carriers with manifest disease (10).

SDH mutations have also been linked to nonparaganglionic tumors. In a recent study we strengthened the etiological association of SDH genes with pituitary neoplasia, renal tumorigenesis and gastric gastrointestinal stromal tumors. We also found that pancreatic neuroendocrine tumors may be part of the SDH-related tumor spectrum (11).

Two founder mutations in $S D H B$ have been identified in Dutch PGL families, the c. $423+1 \mathrm{G}>\mathrm{A}$ splice site mutation and the c.201-4429_287-933del, p.(Cys68fs) mutation, also annotated as a deletion of exon $3(12,13)$. The aim of this study was to obtain a better impression of the phenotype of $S D H B$ mutation carriers, especially of the two founder mutations. Therefore, we investigated the clinical and biochemical characteristics of diseaseaffected and unaffected $S D H B$ germline mutation carriers in a nationwide study in seven academic centers in the Netherlands.

\section{Subjects and methods}

In this retrospective nationwide study, all SDHB germline mutation carriers diagnosed before 2014 were included in the analysis. All included persons gave written informed consent and in case of persons under 18 years of age, written informed consent was obtained from their parents. Follow-up ended on July 1, 2014 or, when lost to follow-up, the date of the last contact with the endocrinologist or otolaryngologist/head and neck surgeon. We evaluated the genetic, clinical, radiological and biochemical data of SDHB mutation carriers identified in seven of the eight clinical genetics centers of the Netherlands: Leiden University Medical Center (Leiden), University Medical Center Groningen (Groningen), Radboud University Medical Center (Nijmegen), VU University Medical Center (Amsterdam), Erasmus Medical Center (Rotterdam), Academic Medical Center (Amsterdam) and University Medical Center Utrecht (Utrecht). Maastricht University Medical Center was not able to participate for technical reasons. However, they only had identified one germline $S D H B$ mutation carrier. Data from 47 SDHB mutation carriers from the Leiden University Medical Center are previously described by van Hulsteijn et al. (14).

In the academic centers, genetic counseling and DNA testing for mutations in the $S D H$ genes are offered to patients with PCC/sPGL and a positive family history for HNPGL or PCC/sPGL, patients with an isolated PCC/sPGL at an early age (younger than 50 years), and all patients with an HNPGL. If a mutation in the $S D H B$ gene is identified, at-risk family members of the index patients are subsequently invited for genetic counseling and DNA testing for the family-specific $S D H B$ mutation. Screening for germline $S D H B$ mutations is performed by direct sequencing using the Sanger method on an ABI 377 Genetic Analyser (Applied Biosystems) and by multiplex ligation-dependent probe amplification (MLPA) using the P226 MLPA kit (MRC Holland, Amsterdam, the Netherlands). SDHB germline variants are classified as in the international guidelines by Plon et al. (15). In this manuscript we report pathogenic or likely 
pathogenic variants, including missense mutations in highly conserved regions that are likely pathogenic, as germline mutations.

All SDHB germline mutation carriers were investigated according to structured protocols used for standard care in the Netherlands for patients with a PGL (www. oncoline.nl/familiair-paraganglioom). They were offered annual clinical surveillance for PGL at the departments of otorhinolaryngology and endocrinology. For mutation carriers older than 18 years of age, screening consisted of magnetic resonance imaging (MRI) of the head and neck region once every three years, and MRI or computed tomography (CT) scans of thorax, abdomen and pelvis once every two years. Annual biochemical screening included the measurement of (nor)epinephrine, vanillylmandelic acid (VMA), dopamine, (nor)metanephrine and/or 3-methoxytyramine (3-MT) in two 24-h urinary samples (depending on the academic center which urinary measurement(s) were done), and/or plasma free (nor) metanephrine. In case of excessive catecholamine secretion (i.e. any value above the upper reference limit), radiological assessment by MRI or CT scans of thorax, abdomen and pelvis and/or ${ }^{123}$ I metaiodobenzylguanidine (MIBG)-scans/positron emission tomography (PET) with 2-deoxy-2-[fluorine-18]fluoro-D-glucose $\left({ }^{18} \mathrm{~F}-\mathrm{FDG} \quad \mathrm{PET}\right)$ scans $/{ }^{18} \mathrm{~F}-\mathrm{L}$-dihydroxyphenylalanine $\quad\left({ }^{18} \mathrm{~F}\right.$-DOPA) PETscans were performed to identify potential sources of excessive catecholamine production outside the head and neck region. In cases without available tumor histology, tumors were classified as paraganglionic based on their specific characteristics on CT and/or MRI. When in doubt, additional nuclear medicine imaging studies were performed in order to confirm the diagnosis.

At the time of this study, there were no national, structured protocols for surveillance in $S D H B$ mutation carriers younger than 18 years of age. Therefore, the method and interval of surveillance in this age category varied between centers. In case of a diagnosis of sPGL, PCC or HNPGL, treatment or intensified periodic examination was offered, guided by the clinical course. In general, for a PCC or sPGL an operation was the preferred treatment of choice. In case of an HNPGL, treatment was guided by the clinical symptoms, tumor characteristics and patient characteristics. Wait and scan policy, radiotherapy or resection were possible treatment options.

An unaffected mutation carrier was defined as a germline mutation carrier without evidence of disease (i.e. HNPGL, sPGL and/or PCC). A disease-affected mutation carrier was defined as a germline mutation carrier with disease, i.e. HNPGL, sPGL and/or PCC.
Malignant disease was defined as the presence of metastases, that is, the presence of chromaffin tissue in locoregional lymphnodes or in non-chromaffin organs distant from the primary tumor, because there are no histological features of the primary tumor that reliably distinguish benign from malignant PGLs.

The study was approved by the Medical Ethics Committee of the Leiden University Medical Center (LUMC; number P13.161), participating centers complied with their local medical ethics committee requirements.

\section{Data analysis}

IBM SPSS Statistics version $20 \cdot 0$ (SPSS) was used for data analysis. Chi-square tests were used to test whether proportions differed significantly, except when an expected cell size was less than five, in which case Fisher's exact was employed. For comparison of disease risks for index patients and relatives Kaplan-Meier curves (One Minus Cum Survival) were plotted. Results are presented as mean \pm S.D. Differences were considered statistically significant at $P \leq 0.05$ (two-sided).

\section{Results}

A total of 194 SDHB germline mutation carriers were included: 61 from the Leiden University Medical Center (Leiden), 61 from the University Medical Center Groningen (Groningen), 29 from the Radboud University Medical Center (Nijmegen), 17 from the VU University Medical Center (Amsterdam), 18 from the Erasmus Medical Center (Rotterdam), four from the Academic Medical Center (Amsterdam) and four from the University Medical Center Utrecht (Utrecht).

In total, 83 men (42.8\%) and 111 women (57.2\%) were included. The median duration of the follow-up was 2.6 years (range: $0-36)$. Eleven persons (5.7\%) were lost to follow-up: six for unknown reasons, three chose not to pursue any follow-up, one emigrated and one continued the follow-up in a non-participating hospital. Seven persons (3.6\%) died: three because of intercurrent disease (lung cancer, metastasized breast cancer and myocardial infarction), one due to progressive disease of a malignant HNPGL (jugular body tumor) with bone metastases, and three due to progressive disease due to a malignant sPGL.

In total, our cohort consisted of 83 (42.3\%) diseaseaffected mutation carriers and 111 (57.2\%) unaffected mutation carriers. From the 111 unaffected mutation carriers, 104 have had complete radiological screening 
(CT/MRI of the head and neck region and CT/MRI of the thorax/abdomen/pelvis). Seven have had either a CT/MRI of the head and neck region (two mutation carriers) or a CT/MRI of the thorax/abdomen/pelvis (five mutation carriers). From the 83 disease-affected mutation carriers, 74 have had complete radiological screening. Nine mutation carriers have had either a CT/MRI of the head and neck region (two mutation carriers) or a CT/MRI of the thorax/ abdomen/pelvis (seven mutation carriers). However, all the mutation carriers, who did not have had complete radiological screening by CT/MRI, did had another (total body) imaging study (i.e. ${ }^{123}$ I MIBG-scans $/{ }^{18}$ F-FDG PETscans $/{ }^{18} \mathrm{~F}$-DOPA PET-scans).

There were 65 index patients and 129 relatives of index patients. Of the 129 relatives, 109 persons (84.5\%) were unaffected mutation carriers. Four index patients were not affected with HNPGL, PCC or sPGL because these patients had DNA testing for other reasons (one with multiple congenital anomalies, one with two renal cell carcinomas (RCCs) and a gastric gastrointestinal stromal tumor (GIST), one was thought to have an HNPGL, but during radiological follow-up the diagnosis of HNPGL was reversed to no evidence of a tumor and the fourth patient was thought to have a PCC, but this turned out to be a non-functioning adrenal adenoma).

\section{Genetics}

Details of $S D H B$ mutations are outlined in Table 1 . Sixty (30.9\%) were carriers of the exon 3 deletion and $46(23.7 \%)$ were carriers of the c. $423+1 \mathrm{G}>\mathrm{A}$ mutation. The c. $654 \mathrm{G}>\mathrm{A}, \mathrm{p} .\left(\operatorname{Trp} 218^{*}\right)$ mutation was present in 19 persons (9.8\%) and the c.653 G>C, p.(Trp218Ser) mutation in 11 persons (5.7\%).

\section{Clinical features}

The mean age at first evaluation at the outpatient clinic was $44.8 \pm 16.0$ years (range $11-76$ ). In total, our cohort comprised of 65 (33.5\%) index patients and 129 (66.5\%) of their relatives.

Clinical characteristics at the end of follow-up of the cohort as a whole and for four most prevalent Dutch $S D H B$ mutations (deletion exon 3, c. $423+1 \mathrm{G}>\mathrm{A}$, c. $654 \mathrm{G}>\mathrm{A}$ and c.653 G>C) are outlined in Table 2 .

Of the whole cohort, 54 mutation carriers $(27.8 \%)$ were clinically affected with one or multiple HNPGLs. Mean age of diagnosis of HNPGL was $45.9 \pm 14.2$ years (range: 11-77). Carotid body tumors were the most
Table $1 S D H B$ germline mutations.

\begin{tabular}{|c|c|c|}
\hline DNA mutation & $\begin{array}{l}\text { SDHB predicted protein } \\
\text { change }\end{array}$ & $\begin{array}{l}\text { Number of } \\
\text { subjects (\%) }\end{array}$ \\
\hline Exon 3 deletion & p.? & $60(31)$ \\
\hline c. $423+1 G>A$ & p.? & $46(24)$ \\
\hline c. $654 \mathrm{G}>\mathrm{A}$ & p. $\left(\operatorname{Trp} 218^{*}\right)$ & $19(10)$ \\
\hline c. $653 \mathrm{G}>\mathrm{C}$ & p.(Trp218Ser) & $11(6)$ \\
\hline c. $574 \mathrm{~T}>\mathrm{C}$ & p.(Cys192Arg) & $8(4)$ \\
\hline c. $200+1 G>A$ & p.? & $6(3)$ \\
\hline c. $137 \mathrm{G}>\mathrm{A}$ & p.(Arg46GIn) & $4(2)$ \\
\hline c. $328 \mathrm{~A}>\mathrm{C}$ & p.(Thr110Pro) & $4(2)$ \\
\hline c. $418 \mathrm{G}>\mathrm{T}$ & p.(Val140Phe) & $4(2)$ \\
\hline c. $725 \mathrm{G}>\mathrm{A}$ & p.(Arg242His) & $3(1.5)$ \\
\hline c. $649 \mathrm{C}>\mathrm{T}$ & p.(Arg217Cys) & $3(1.5)$ \\
\hline c. $590 C>G$ & p.(Pro197Arg) & $3(1.5)$ \\
\hline c.686_725del & p.(Glu229fs) & $3(1.5)$ \\
\hline c. $343 \bar{C}>\mathrm{T}$ & p. $\left(\operatorname{Arg} 115^{*}\right)$ & $3(1.5)$ \\
\hline c. $292 \mathrm{~T}>\mathrm{C}$ & p.(Cys98Arg) & $2(1)$ \\
\hline $\begin{array}{l}\text { Deletion promoter } \\
\text { and exon } 1\end{array}$ & p.? & $1(0.5)$ \\
\hline $\begin{array}{l}\text { Deletion promoter till } \\
\text { exon } 8\end{array}$ & p.0 & $2(1)$ \\
\hline Exon 2 deletion & p.? & $2(1)$ \\
\hline Exon 1 deletion & p.? & $2(1)$ \\
\hline c.713delT & p.(Phe238fs) & $1(0.5)$ \\
\hline c.727T >A & p.(Cys243Ser) & $1(0.5)$ \\
\hline c. $761 \mathrm{C}>\mathrm{T}$ & p.(Pro254Leu) & $1(0.5)$ \\
\hline c. $626 \mathrm{C}>\mathrm{T}$ & p.(Pro209Leu) & $1(0.5)$ \\
\hline c. $380 \mathrm{~T}>\mathrm{C}$ & p.(Ile127Thr) & $1(0.5)$ \\
\hline c. $325 \mathrm{~A}>\mathrm{C}$ & p.(Asn 109His) & $1(0.5)$ \\
\hline c. $1 \mathrm{~A}>\mathrm{G}$ & p.? & $1(0.5)$ \\
\hline c. $119 \mathrm{~A}>\mathrm{C}$ & p.(Lys40Thr) & $1(0.5)$ \\
\hline
\end{tabular}

prevalent HNPGLs (in 11.3\%), followed by jugular body tumors (in 7.2\%) and vagal body tumors (in 6.2\%). Twenty-seven carriers (50.0\%) had an operation for their HNPGL and 15 (27.8\%) received radiotherapy.

Four patients $(2.1 \%)$ were clinically affected with a PCC. Mean age of diagnosis of PCC was $36.2 \pm 16.3$ years (range 19-56). Clinical characteristics are detailed in Table 3.

Twenty-six mutation carriers (13.4\%) were clinically affected with one or more sPGLs. Mean age of diagnosis of sPGL was $33.4 \pm 12.7$ years (range: 10-66). None of the 26 mutation carriers suffered from an HNPGL. More than half of the patients with an sPGL had elevated hormone levels. Five carriers had two sPGLs. The sPGLs were mainly located in the abdominal/pelvic region (28 tumors); there were only three thoracic PGLs. Eight persons carried the exon 3 deletion, five the $c .423+1 \mathrm{G}>$ A mutation, two the c. $343 \mathrm{C}>\mathrm{T}$ mutation and another two the c. $200+1 \mathrm{G}>\mathrm{A}$ mutation. Twelve of the 26 carriers with one or more sPGLs had metastatic disease and three of them died due to progressive metastatic disease. Clinical characteristics and biochemical phenotypes are detailed in Table 4 . 
Table 2 Clinical phenotypes of specific SDHB germline mutations.

\begin{tabular}{|c|c|c|c|c|c|}
\hline & Total cohort $(n=194)$ & Exon 3 deletion $(n=60)$ & c. $423+1 \mathrm{G}>\mathbf{A}(n=46)$ & c.654G > A $(n=19)$ & c.653G $>$ C $(n=11)$ \\
\hline \multicolumn{6}{|l|}{ Gender } \\
\hline Man & $83(42.8 \%)$ & $29(48.3 \%)$ & $18(39.1 \%)$ & $8(42.1 \%)$ & $2(18.2 \%)$ \\
\hline Woman & $111(57.2 \%)$ & $31(51.7 \%)$ & $28(60.9 \%)$ & $11(57.9 \%)$ & $9(81.8 \%)$ \\
\hline Age $(\text { mean } \pm \text { S.D. })^{a}$ & $44.8 \pm 16.0$ & $43.2 \pm 15.3$ & $51.0 \pm 14.5$ & $44.0 \pm 18.1$ & $49.1 \pm 11.7$ \\
\hline Family history positive & $129(66.5 \%)$ & $40(66.7 \%)$ & $35(76.1 \%)$ & $18(94.7 \%)$ & $8(72.7 \%)$ \\
\hline HNPGL & $54(27.8 \%)$ & $18(30.0 \%)$ & $11(23.9 \%)$ & $1(5.3 \%)$ & $3(27.3 \%)$ \\
\hline $1 \mathrm{HNPGL}$ & 47 & 15 & 10 & 1 & 3 \\
\hline 2 HNPGL & 6 & 2 & 1 & 0 & 0 \\
\hline 3 HNPGL & 1 & 1 & 0 & 0 & 0 \\
\hline $\mathrm{CBT}$ & $22(11.3 \%)$ & $6(10.0 \%)$ & $3(6.5 \%)$ & 1 & $2(18.2 \%)$ \\
\hline Left & 11 & 3 & 3 & 0 & 1 \\
\hline Right & 9 & 4 & 0 & 1 & 1 \\
\hline Bilateral & 2 & 0 & 0 & 0 & 0 \\
\hline VBT & $12(6.2 \%)$ & $4(6.6 \%)$ & $3(6.5 \%)$ & 0 & $1(9.1 \%)$ \\
\hline Left & 6 & 2 & 0 & & 1 \\
\hline Right & 6 & 2 & 3 & & 0 \\
\hline Bilateral & 0 & 0 & 0 & & 0 \\
\hline JBT & $14(7.2 \%)$ & $7(11.7 \%)$ & $5(10.9 \%)$ & 0 & 0 \\
\hline Left & 8 & 5 & 3 & & \\
\hline Right & 5 & 1 & 2 & & \\
\hline Bilateral & 1 & 1 & 0 & & \\
\hline Tymp & $10(5.2 \%)$ & $4(6.7 \%)$ & $1(2.2 \%)$ & 0 & 0 \\
\hline Left & 5 & 1 & 1 & & \\
\hline Right & 5 & 3 & 0 & & \\
\hline Bilateral & 0 & 0 & 0 & & \\
\hline Other (HNPGL) & 1 (right tonsil) & 0 & 0 & 0 & 0 \\
\hline Age HNPGL ${ }^{b}$ & $45.9 \pm 14.2$ & $47.0 \pm 14.8$ & $50.6 \pm 11.2$ & 27.2 & $44.8 \pm 14.3$ \\
\hline Operation HNPGL & $27(50.0 \%)$ & $8(44.4 \%)$ & $4(36.4 \%)$ & 0 & $1(33.3 \%)$ \\
\hline Radiotherapy HNPGL & $15(27.8 \%)$ & $8(44.4 \%)$ & $4(36.4 \%)$ & 0 & 0 \\
\hline PCC & $4(2.1 \%)$ & $1(1.7 \%)$ & 0 & 0 & $1(9.1 \%)$ \\
\hline Left & 3 & 1 & & & 1 \\
\hline Right & 1 & 0 & & & \\
\hline sPGLc & $26(13.4 \%)$ & $8(13.3 \%)$ & $5(10.9 \%)$ & $1(5.3 \%)$ & $1(9.1 \%)$ \\
\hline Operation sPGL & 25 & $8(100 \%)$ & $5(100 \%)$ & & $1(100 \%)$ \\
\hline Malignant PGL/PCC & $15(7.7 \%)$ & $5(8.3 \%)$ & $1(2.2 \%)$ & $1(5.3 \%)$ & $1(9.1 \%)$ \\
\hline Other tumors ${ }^{\mathrm{d}}$ & $17(8.8 \%)$ & $5(8.3 \%)$ & $7(15.2 \%)^{g}$ & 0 & 0 \\
\hline Mamma ca. & 1 & 0 & 1 & & \\
\hline Renal cell ca. & $3^{e}$ & 2 & 1 & & \\
\hline Basal cell ca. & 2 & 0 & 1 & & \\
\hline Melanoma & 2 & 1 & 1 & & \\
\hline Lung ca. & 1 & 0 & 1 & & \\
\hline Prostate ca. & 1 & 0 & 0 & & \\
\hline Colon ca. & 2 & 0 & 2 & & \\
\hline Meibomian gland & 1 & 0 & 0 & & \\
\hline Synovial sarcoma & 1 & 1 & 0 & & \\
\hline Ovarian ca. & 1 & 0 & 1 & & \\
\hline Gastric GIST & $2^{f}$ & 0 & 1 & & \\
\hline Micro-PRL & 1 & 0 & 0 & & \\
\hline Pituitary incidentaloma & 1 & 1 & 0 & & \\
\hline \multicolumn{6}{|c|}{ Disease status at last follow-up } \\
\hline NED & $133(68.6 \%)$ & $42(70.0 \%)$ & $32(69.6 \%)$ & $16(84.2 \%)$ & $8(72.7 \%)$ \\
\hline AWD & $43(22.2 \%)$ & $13(21.7 \%)$ & $9(19.6 \%)$ & $1(5.3 \%)$ & $3(27.3 \%)$ \\
\hline LTF & $11(5.7 \%)$ & $3(5.0 \%)$ & $2(4.3 \%)$ & $1(5.3 \%)$ & 0 \\
\hline DOD & $4(2.1 \%)$ & $2(3.3 \%)$ & $1(2.2 \%)$ & $1(5.3 \%)$ & 0 \\
\hline DID & $3(1.5 \%)$ & 0 & $2(4.3 \%)$ & 0 & 0 \\
\hline
\end{tabular}

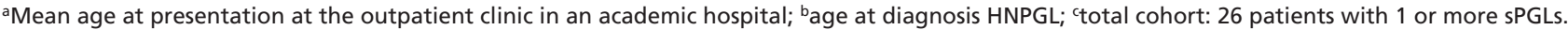

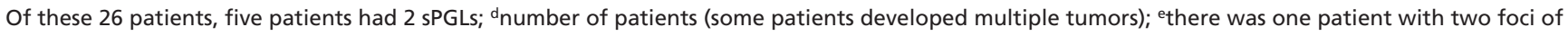
renal cell carcinoma (RCC) on the left side and one RCC on the right side. The other 2 patients both had 1 foci of a RCC; fone patient developed three renal cell carcinomas ( 2 foci on the left side en one on the right side) as well as a gastrointestinal stromal tumor (GIST); ${ }^{9}$ one patient with rectal cancer and ovarian cancer, one patient with three RCC as well as a GIST.

AWD, alive with disease; ca., carcinoma; CBT, carotid body tumor; DID, dead of intercurrent disease; DOD, dead of disease; GIST, gastrointestinal stromal tumor; HNPGL, head and neck paraganglioma; JBT, jugular body tumor; LTF, loss to follow-up; NED, no evidence of disease; PCC, pheochromocytoma; PRL, prolactinoma; SPGL, sympathetic paraganglioma; Tymp, tympanicum body tumor; VBT, vagal body tumor. 
Table 3 Clinical characteristics of the 4 patients with a pheochromocytoma.

\begin{tabular}{|c|c|c|c|c|c|c|c|c|}
\hline Case & Sex & SDHB mutation & Location & Presenting symptoms & $\mathbf{A g e}^{\mathrm{a}}$ & $\begin{array}{l}\text { Biochemical phenotype } \\
\text { (urinary measurements) }\end{array}$ & $\begin{array}{l}\text { Biochemical } \\
\text { phenotype } \\
\text { (blood) }\end{array}$ & Outcome \\
\hline 1 & $\mathrm{M}$ & Exon 2 deletion & Right & $\begin{array}{l}\text { Hypertension, flushes, } \\
\text { palpitations }\end{array}$ & 40 & NMN elevated, M normal & NA & NED \\
\hline 2 & $\mathrm{~F}$ & c. $343 \mathrm{C}>\mathrm{T}$ & Left & Collaps & 28 & NA & NA & NED \\
\hline 3 & $\mathrm{~F}$ & Exon 3 deletion & Left & $\begin{array}{l}\text { None, brother with } S D H B \\
\text { mutation }\end{array}$ & 56 & $\begin{array}{l}\text { M, NMN, 3-MT slightly } \\
\text { elevated }\end{array}$ & NA & NED \\
\hline 4 & $\mathrm{~F}$ & c. $653 \mathrm{G}>\mathrm{C}$ & Left & Hypertension, flushes & 19 & NAV & NAV & $\begin{array}{l}\text { AWD (vagal } \\
\text { body tumor) }\end{array}$ \\
\hline
\end{tabular}

${ }^{a}$ Age at diagnosis of pheochromocytoma.

F, female; M, male; MN, metanephrine; NA, not assessed; NAV, not available; NED, no evidence of disease; NMN, normetanephrine.

Out of the whole cohort of $S D H B$ germline mutation carriers, 15/194 (7.7\%) developed metastatic PGL. Clinical characteristics, treatment and outcome of the patients with metastatic disease are displayed in detail in Table 5 . Treatment of the primary tumor existed of surgery in all patients. None of the 47 mutation carriers described previously have developed metastatic disease since our publication in 2014 (14).

Seventeen mutation carriers $(8.8 \%)$ developed a total of 21 non-paraganglionic tumors. Three patients developed a total of five (histology confirmed) renal tumors. Four of those tumors were described previously and classified as SDH-deficient renal carcinomas $(11,16$, 17). Two patients developed a RCC on one side (one clear cell carcinoma and one SDH-deficient carcinoma), and one patient developed two foci of a RCC on the left side and one on the right side (all three SDH-deficient renal carcinomas). This latter patient also developed an SDHdeficient gastric GIST and has been described previously (11). There was one other patient with an SDH-deficient gastric GIST. Furthermore, there were two patients with a basal cell carcinoma, two with a melanoma, one with a squamous cell lung carcinoma, one with (metastasized) breast cancer, one with prostate cancer, one with a meibomian gland (adeno) carcinoma and one with a (metastasized) synovial sarcoma. In addition, two patients had a rectal cancer and one had ovarian cancer (granulosa cell tumor).

Besides these malignancies, one person developed a microprolactinoma and one person had a nonfunctioning pituitary incidentaloma, both of which underwent radiological follow-up without available biopsy or surgically-resected material.

Of these 17 mutation carriers with non-paraganglionic tumors, only three patients had also paraganglionic tumors (all three patients had an HNPGL).
The clinical characteristics of the index patients vs relatives are outlined in Table 6 and the age-related disease risk for index patients (probands) vs relatives is outlined in Fig. 1.

To explore potential differences in clinical phenotypes related to the specific mutations within the $S D H B$ gene, carriers of the two most common $S D H B$ mutations in the Netherlands (exon 3 deletion and c. $423+1 G>A$ ) were compared. Statistical analyses showed no significant differences in number and location of HNPGLs, sPGLs or PCCs, nor in the occurrence of malignant disease or other tumors.

\section{Discussion}

In this nationwide multicenter study we assessed the phenotypes of 194 SDHB germline mutation carriers. Our cohort consisted of $83(42.8 \%)$ disease-affected mutation carriers and 111 (57.2\%) unaffected mutation carriers. Fifty-four carriers $(27.8 \%)$ were clinically affected with one or multiple HNPGLs. Only four patients (2.1\%) were clinically affected with a PCC and 26 (13.4\%) with one or more sPGLs. Fifteen patients (7.7\%) developed metastatic disease.

Previous studies have reported much higher rates for developing PCC and sPGLs, $18-52 \%$ and $59-84 \%$ respectively $(5,6,8,18)$. For various reasons, it is quite difficult to directly compare our results with those reported in the literature. The majority of previously published studies include a high proportion of index patients. This may result in ascertainment bias and therefore overestimation of the risk of developing HNPGL, PCC, sPGL or malignant disease. A recently published study by the French network on PGL/PCC in SDHx mutation carriers included 124 SDHB mutation carriers, 39 (31\%) of whom were index patients and 85 persons (69\%) 
Table 4 Characteristics of 26 patients with sympathetic paragangliomas.

\begin{tabular}{|c|c|c|c|c|c|c|c|}
\hline Case & Sex & SDHB mutation & Location SPGL & Age $^{a}$ (year) & $\begin{array}{l}\text { Malignant } \\
\text { disease }\end{array}$ & Tumor reduction therapy & Outcome \\
\hline 1 & $\mathrm{~F}$ & c. $343 C>T$ & $\begin{array}{l}\text { Retroperitoneal and } \\
\text { presacral }\end{array}$ & 31 & No & Surgery & No evidence of disease \\
\hline 2 & $\mathrm{~F}$ & Exon 3 deletion & Para-aortic & 41 & No & Surgery (non-radical) & Alive with disease \\
\hline 3 & M & c. $200+1 G>A$ & $\begin{array}{l}\text { Retroperitoneal } \\
\text { (pararenal) }\end{array}$ & 42 & Yes & $\begin{array}{l}\text { Surgery, }{ }^{131} \mathrm{I}-\mathrm{MIBBG} \text { therapy, } \\
\text { radiotherapy }\end{array}$ & $\begin{array}{l}\text { Alive at age } 52, \text { with } \\
\text { disease }\end{array}$ \\
\hline 4 & M & Exon 3 deletion & Retropancreatic & 11 & No & Surgery & No evidence of disease \\
\hline 5 & M & Exon 3 deletion & $\begin{array}{l}\text { Thoracic (vertebra Th6) } \\
\text { and intra-abdominal }\end{array}$ & 10 and 32 & Yes & $\begin{array}{l}\text { Surgery, chemotherapy } \\
\text { radiotherapy }{ }^{131} I \text {-MIBG } \\
\text { therapy, RFA }\end{array}$ & $\begin{array}{l}\text { Alive at age } 37 \\
\text { without evidence of } \\
\text { disease }\end{array}$ \\
\hline 6 & $\mathrm{~F}$ & Exon 1 deletion & Renal hilum & 28 & No & Surgery & No evidence of disease \\
\hline 7 & M & Exon 3 deletion & Para-aortic abdominal & 42 & No & Surgery & No evidence of disease \\
\hline 8 & $\mathrm{~F}$ & $c .423+1 G>A$ & Retroperitoneal & 36 & No & Surgery & No evidence of disease \\
\hline 9 & $\mathrm{~F}$ & c.725G $>A$ & Para-adrenal & 40 & Yes & $\begin{array}{l}\text { Surgery, Lutetium } \\
\text { octreotate therapy }\end{array}$ & $\begin{array}{l}\text { Alive at age } 51, \text { with } \\
\text { disease }\end{array}$ \\
\hline 10 & $\mathrm{~F}$ & c. $423+1 G>A$ & Para-iliac (2 lesions) & 19 & No & Surgery & No evidence of disease \\
\hline 11 & M & c. $423+1 G>A$ & Para-aortic abdominal & 31 & No & Surgery & No evidence of disease \\
\hline 12 & $\mathrm{~F}$ & c. $653 G>C$ & Retroperitoneal & 66 & Yes & Surgery, ${ }^{131}$ I-MIBG therapy & $\begin{array}{l}\text { Alive at age } 78, \text { with } \\
\text { disease }\end{array}$ \\
\hline 13 & M & Exon 3 deletion & Retroperitoneal & 37 & Yes & Surgery & $\begin{array}{l}\text { Alive at age } 40 \text {, with } \\
\text { disease }\end{array}$ \\
\hline 14 & $\mathrm{M}$ & Exon 3 deletion & $\begin{array}{l}\text { Bladder and } \\
\text { retroperitoneal }\end{array}$ & 27 & No & Surgery & No evidence of disease \\
\hline 15 & M & c. $423+1 G>A$ & Para-aortic abdominal & 38 & No & Surgery & No evidence of disease \\
\hline 16 & M & c. $325 \mathrm{~A}>\mathrm{C}$ & Para-aortic abdominal & 30 & Yes & Surgery, ${ }^{131}$ I-MIBG therapy & $\begin{array}{l}\text { Alive at age } 46 \text {, with } \\
\text { disease }\end{array}$ \\
\hline 17 & M & c. $200+1 G>A$ & Bladder & 45 & Yes & $\begin{array}{l}\text { Surgery, radiotherapy, } \\
\text { chemotherapy (CVD) }\end{array}$ & $\begin{array}{l}\text { Alive at age 47, with } \\
\text { disease }\end{array}$ \\
\hline 18 & M & c. $574 \mathrm{~T}>\mathrm{C}$ & Liver hilum & 24 & No & Surgery & No evidence of disease \\
\hline 19 & $\mathrm{~F}$ & c. $727 \mathrm{~T}>\mathrm{A}$ & $\begin{array}{l}\text { Retroperitoneal } \\
\text { (para-aortic) }\end{array}$ & 52 & Yes & Surgery, radiotherapy & $\begin{array}{l}\text { Died at age } 63 \text {, due to } \\
\text { intercurrent disease }\end{array}$ \\
\hline 20 & $\mathrm{~F}$ & c. $343 C>T$ & Thoracic & 14 & No & Surgery & Loss to follow-up \\
\hline 21 & $\mathrm{~F}$ & c.686_725del & $\begin{array}{l}\text { Para-aortic abdominal } \\
\text { and para-vertebral } \\
\text { (Th3/Th4) }\end{array}$ & 39 & No & Follow-up & Alive with disease \\
\hline 22 & M & c. $626 \mathrm{C}>\mathrm{T}$ & Bladder & 42 & Yes & $\begin{array}{c}\text { Radiotherapy, Firstmappp } \\
\text { trial (started June 2014) }\end{array}$ & $\begin{array}{l}\text { Alive at age } 52, \text { with } \\
\text { disease }\end{array}$ \\
\hline 23 & $\mathrm{~F}$ & c. $423+1 G>A$ & Pararenal & 31 & No & Surgery & No evidence of disease \\
\hline 24 & $M$ & Exon 3 deletion & Presacral & 28 & Yes & $\begin{array}{l}\text { Surgery, }{ }^{131} \text { I-MIBG therapy, } \\
\text { radiotherapy }\end{array}$ & $\begin{array}{l}\text { Dead of disease: died } \\
\text { at age } 32 \text { due to } \\
\text { progressive disease }\end{array}$ \\
\hline 25 & $\mathrm{~F}$ & c.654G $>A$ & Bladder & 19 & Yes & $\begin{array}{l}\text { Surgery (primary bladder } \\
\text { PGL) sunitinib } \\
\text { (metastases) }\end{array}$ & $\begin{array}{l}\text { Dead of disease: died } \\
\text { at age } 62 \text { due to } \\
\text { progressive disease }\end{array}$ \\
\hline 26 & $\mathrm{~F}$ & Exon 3 deletion & $\begin{array}{l}\text { Para-vertebral } \\
\text { abdominal }\end{array}$ & 33 & Yes & $\begin{array}{l}\text { Surgery, }{ }^{131} \text { I-MIBG therapy, } \\
\text { radiotherapy }\end{array}$ & $\begin{array}{l}\text { Dead of disease: died } \\
\text { at age } 37 \text { due to } \\
\text { progressive disease }\end{array}$ \\
\hline
\end{tabular}

${ }^{a}$ Age at diagnosis of sympathetic paraganglioma; *catecholamine measurements at time of primary tumor not available; * ${ }^{*}$ catecholamine excess developed with lymph node metastases, not at time of primary tumor; ${ }^{* *}{ }^{*}$ catecholamine excess developed at time of malignant disease, not at time of primary tumor.

3-MT, 3-methoxytyramine; CVD, cyclophosphamide, vincristine, dacarbazine; D, dopamine; E, epinephrine; F, female; Firstmappp, randomized, doubleblind, phase II, international, multicenter study which is dedicated to determine the efficacy of sunitinib on the progression-free survival at 12 months in patients with progressive malignant pheochromocytoma and paraganglioma; HNPGL, head and neck paraganglioma; $\mathrm{M}$, male; $\mathrm{MN}$, metanephrine; NA, not assessed; NE, norepinephrine; NMN, normetanephrine; PGL, paraganglioma; RFA, radiofrequency ablation; VMA, vanillylmandelic acid.

were relatives of index patients (19). This cohort seems to resemble the proportions of our study cohort, and the prevalences of PCC (1.6\%) and sPGL (6.5\%) found in their study are more comparable to the results in our current study (2.1\% and $13.4 \%$ respectively). The low percentages of PCC/sPGLs reported in France and in the present study indicate that the high percentages described in several other studies are likely to be the result of ascertainment 
Table 5 Clinical characteristics of patients with metastatic paragangliomas.

\begin{tabular}{|c|c|c|c|c|c|c|c|c|}
\hline Case & Sex & SDHB mutation & Location PGL & Age $^{a}$ (years) & $\begin{array}{l}\text { Age }^{\mathbf{b}} \\
\text { (years) }\end{array}$ & $\begin{array}{l}\text { Location } \\
\text { metastases }\end{array}$ & $\begin{array}{l}\text { Treatment malignant } \\
\text { disease }\end{array}$ & Outcome \\
\hline 1 & $\mathrm{M}$ & c. $200+1 G>A$ & $\begin{array}{l}\overline{\text { Retroperitoneal }} \\
\text { (pararenal) }\end{array}$ & 42 & 45 & Bone & $\begin{array}{l}\text { Surgery, }{ }^{131} \text { I-MIBG } \\
\text { therapy, } \\
\text { radiotherapy }\end{array}$ & $\begin{array}{l}\text { Alive at age } 52, \\
\text { with disease }\end{array}$ \\
\hline 2 & $M$ & Exon 3 deletion & $\begin{array}{l}\text { Thoracic } \\
\text { (vertebra Th6) }\end{array}$ & 10 & 13 & Intra-thoracic & $\begin{array}{l}\text { Surgery, } \\
\text { chemotherapy } \\
\text { radiotherapy } \\
{ }^{131} \text { I-MIBG therapy, } \\
\text { RFA }\end{array}$ & $\begin{array}{l}\text { Alive at age } 37, \\
\text { without evidence } \\
\text { of disease }\end{array}$ \\
\hline 3 & $\mathrm{~F}$ & c. $418 \mathrm{G}>\mathrm{T}$ & Right tonsil & 18 & 20 & $\begin{array}{l}\text { Lymph nodes, } \\
\text { bone } \\
\text { (vertebra) }\end{array}$ & Surgery, radiotherapy & $\begin{array}{l}\text { LTF, follow-up till } \\
\text { age } 22, \text { alive with } \\
\text { disease }\end{array}$ \\
\hline 4 & $\mathrm{~F}$ & c. $725 \mathrm{G}>\mathrm{A}$ & Para-adrenal & 40 & 45 & $\begin{array}{l}\text { Lymph nodes, } \\
\text { bone }\end{array}$ & $\begin{array}{l}\text { Surgery and } \\
{ }^{177} \text { Lutetium } \\
\text { octreotate therapy }\end{array}$ & $\begin{array}{l}\text { Alive at age } 51, \\
\text { with disease }\end{array}$ \\
\hline 5 & M & c. $423+1 G>A$ & Jugular body & 48 & 57 & Bone (vertebra) & None & $\begin{array}{l}\text { Died at age } 57 \text {, due } \\
\text { to rapidly } \\
\text { progressive } \\
\text { malignant disease }\end{array}$ \\
\hline 6 & $\mathrm{~F}$ & Exon 3 deletion & Carotid body & 35 & 66 & $\begin{array}{l}\text { Lymph nodes, } \\
\text { bone }\end{array}$ & $\begin{array}{l}\text { None (not within } \\
\text { study period) }\end{array}$ & $\begin{array}{l}\text { Alive at age } 66, \\
\text { with disease }\end{array}$ \\
\hline 7 & $\mathrm{~F}$ & c. $653 G>C$ & Retroperitoneal & 66 & 70 & $\begin{array}{l}\text { Lymph nodes, } \\
\text { bone }\end{array}$ & ${ }^{131}$ I-MIBG therapy & $\begin{array}{l}\text { Alive at age } 78, \\
\text { with disease }\end{array}$ \\
\hline 8 & M & Exon 3 deletion & Retroperitoneal & 37 & 38 & Lymph nodes & Surgery & $\begin{array}{l}\text { Alive at age } 40, \\
\text { with disease }\end{array}$ \\
\hline 9 & $M$ & c. $325 \mathrm{~A}>\mathrm{C}$ & $\begin{array}{l}\text { Para-aortic } \\
\text { abdominal }\end{array}$ & 30 & 39 & $\begin{array}{l}\text { Lymph nodes, } \\
\text { bone, lung }\end{array}$ & ${ }^{131}$ I-MIBG therapy & $\begin{array}{l}\text { Alive at age } 46, \\
\text { with disease }\end{array}$ \\
\hline 10 & $M$ & c. $200+1 G>A$ & Bladder & 45 & 45 & $\begin{array}{l}\text { Lymph nodes, } \\
\text { bone, lung }\end{array}$ & $\begin{array}{l}\text { Surgery, radiotherapy, } \\
\text { chemotherapy } \\
\text { (CVD) }\end{array}$ & $\begin{array}{l}\text { Alive at age } 47, \\
\text { with disease }\end{array}$ \\
\hline 11 & $\mathrm{~F}$ & c.727T $>A$ & $\begin{array}{l}\text { Retroperitoneal } \\
\text { (para-aortic) }\end{array}$ & 52 & 55 & Bone & Radiotherapy & $\begin{array}{l}\text { Died at age } 63 \text {, due } \\
\text { to intercurrent } \\
\text { disease }\end{array}$ \\
\hline 12 & M & c. $626 C>T$ & Bladder & 42 & 46 & $\begin{array}{l}\text { Lymph nodes, } \\
\text { bone }\end{array}$ & $\begin{array}{l}\text { Radiotherapy, } \\
\text { Firstmappp trial } \\
\text { (started June 2014) }\end{array}$ & $\begin{array}{l}\text { Alive at age } 52, \\
\text { with disease }\end{array}$ \\
\hline 13 & $M$ & Exon 3 deletion & Presacral & 28 & 28 & Bone & $\begin{array}{l}\text { Surgery, }{ }^{131} \text { I-MIBG } \\
\text { therapy, } \\
\text { radiotherapy }\end{array}$ & $\begin{array}{l}\text { Died at age } 32 \text { due } \\
\text { to progressive } \\
\text { disease }\end{array}$ \\
\hline 14 & $\mathrm{~F}$ & c. $654 \mathrm{G}>\mathrm{A}$ & Bladder & 19 & 58 & $\begin{array}{l}\text { Lymph nodes, } \\
\text { bone }\end{array}$ & sunitinib & $\begin{array}{l}\text { Died at age } 62 \text { due } \\
\text { to progressive } \\
\text { disease }\end{array}$ \\
\hline 15 & $\mathrm{~F}$ & Exon 3 deletion & $\begin{array}{l}\text { Para-vertebral } \\
\text { abdominal }\end{array}$ & 33 & 33 & $\begin{array}{l}\text { Lymph nodes, } \\
\text { bone }\end{array}$ & $\begin{array}{l}\text { Surgery, }{ }^{131} \text { I-MIBG } \\
\text { therapy, } \\
\text { radiotherapy }\end{array}$ & $\begin{array}{l}\text { Died at age } 37 \text { due } \\
\text { to progressive } \\
\text { disease }\end{array}$ \\
\hline
\end{tabular}

${ }^{a}$ Age at diagnosis of paraganglioma; bage at diagnosis of malignant disease.

CBT, carotid body tumor; CVD, cyclophosphamide, vincristine, dacarbazine; F, female; Firstmappp, randomized, double-blind, phase II, international, multicenter study which is dedicated to determine the efficacy of sunitinib on the progression-free survival at 12 months in patients with progressive malignant pheochromocytoma and paraganglioma; HNPGL, head and neck PGL; LTF, loss to follow-up; M, male; PGL, paraganglioma;

RFA, radiofrequency ablation; Th6, 6th thoracic vertebra.

bias. Furthermore, it should be noted that the percentages mentioned in most studies are calculated using the total number of tumors divided by the total number of patients with any tumor, thereby taking only disease-affected persons into account. Removal of all unaffected mutation carriers from our cohort (111 subjects) would give a

Table 6 Clinical characteristics of index patients and relatives.

\begin{tabular}{|c|c|c|c|c|c|c|}
\hline & Age $($ mean \pm S.D. $)$ & Follow-up (median, year) & HNPGL $(\%)$ & PCC (\%) & SPGL (\%) & Malignant PGL/PCC \\
\hline$\overline{\text { Index patients (65) }}$ & $43.6 \pm 14.8$ & 4.5 & $38(58.5)$ & $3(4.6)$ & $21(32.3)$ & $15(23.1)$ \\
\hline Relatives (129) & $45.4 \pm 16.6$ & 2.0 & $16(12.4)$ & $1(0.8)$ & $5(3.9)$ & 0 \\
\hline
\end{tabular}



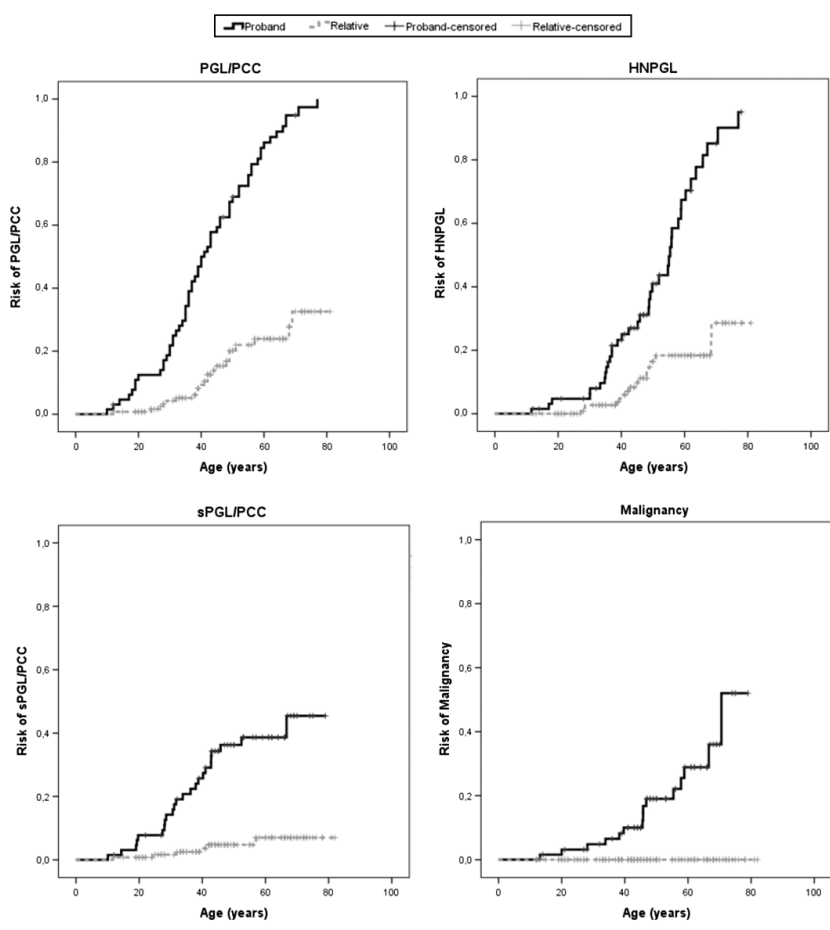

Figure 1

Comparison of age at onset in SDHB mutations carriers: index patients (probands) vs relatives. PGL/PCC, risk of (all) paragangliomas/pheochromocytoma; HNPGL, risk of head and neck paraganglioma; sPGL/PCC, risk of sympathetic paraganglioma/pheochromocytoma; malignancy, risk of malignancy.

figure for PCC of 4 in 83 (4.8\%) and 26 in 83 (31.3\%) for sPGL. Even if we take only disease-affected individuals into account, our figures are substantially lower than in previous studies that have assessed clinical characteristics in $S D H B$ mutation carriers. By contrast, we found a relatively high frequency of HNPGLs (27.8\%) among SDHB mutation carriers compared with other studies $(3-31 \%)(5,6,8,18)$ and even when compared with that of the French network (14.5\%) (19). If only the diseaseaffected mutation carriers were taken into account, the prevalence of HNPGL was as high as 54/83 (65.1\%) in our cohort, nearly double the frequency reported previously in disease-affected subjects $(5,6,8)$. This might in part be explained by the observation that in our study the proportion of HNPGL patients with a positive family history (i.e. non-index HNPGL patients) is $29.6 \%(16 / 54)$. The large majority of these patients had no symptoms and had not yet come to medical attention. The genetic testing of relatives and structured follow-up protocols of persons with a $S D H B$ mutation in the Netherlands identifies a relatively high number of asymptomatic mutation carriers, with or without tumors, allowing for a more accurate representation of the phenotype of $S D H B$ mutation carriers.

The observation that the majority of $S D H B$-linked patients develop an HNPGL furthermore underlines the importance of radiological screening of the head and neck region in $S D H B$ mutation carriers.

Only fifteen patients (7.7\%) in the entire cohort, including both disease-affected and unaffected mutation carriers, developed metastatic PGL. In three of these patients (20\%) the primary tumor was an HNPGL (including one in the tonsil) and in 12 patients (80\%) the primary tumor was an sPGL. Removal of all unaffected mutation carriers (111 subjects) results in a prevalence of metastatic disease by $18.1 \%(15 / 83)$ in PGL/PCC patients. Taking into account only the sPGL patients, the malignancy risk is as high a $46.2 \%(12 / 26)$. For HNPGL patients, this malignancy rate was 5.6\% (3/54). This means that the malignancy risk for patients already suffering from an sPGL is high, which has implications for the follow-up of those patients. Srirangalingam et al. reported metastatic PGL in five of 16 (31\%) disease-affected subjects (8). However, the malignancy rate for the entire cohort was $16 \%(5 / 32)$. The rates of malignancy reported in the literature are calculated based on disease-affected subjects and vary from 31 to $97 \%(5,6,7,8,9)$. These reported malignancy rates are however most likely also inflated because of selection bias in referral-based studies. Alternatively, the discrepancy in malignancy rates may also be a result of variable follow-up times $(7,8)$. A recent systematic review of prevalence studies comprising both asymptomatic $S D H B$ mutation carriers and $S D H B$ mutation carriers with manifest non-malignant PGL documented a pooled risk for developing metastatic PGL of 13 and $23 \%$ respectively (10), also much lower than previously reported $(20,21)$. In the fifteen patients with metastatic PGL, we found a wide range of time to metastatic disease (0-39.2 years). This is in line with previously published results. Timmers et al. found a range from 0 to 17 years (7) and Srirangalingam et al. between 1.5 and 25 years (8). Because it is not possible to diagnose malignancy based on histopathology of the primary tumor, only if metastatic disease is present, the current and previously reported wide ranges of time to metastatic transformation underscore the need for an extended follow-up in patients with an SDHB mutation, especially in disease-affected mutation carriers. The median duration of follow-up is 2.6 years in this study, which is a limitation of this study. However, the follow-up time is relatively short due to a shorter follow-up of relatives compared to index patients. 
Future studies with a longer duration of follow-up are needed to validate our results.

Our findings show a relatively mild phenotype of $S D H B$ mutations in the Netherlands. One might hypothesize that this could be associated with the low altitude and therefore relatively high oxygen levels in the Netherlands (22). However, studying a large cohort from a single country provides a more homogeneous study population and the inclusion of unaffected mutation carriers should provide better information on actual tumor risks than series that include mainly index patients (18). The high proportion of unaffected mutation carriers in our study seems to reflect an active testing protocol in the Netherlands of at-risk family members of the index patients, who are advised to undergo genetic counseling and DNA testing for the family-specific SDHB mutation. Lower lifetime cancer risks have also been established for other genetic tumor syndromes following the inclusion of unaffected mutation carriers, one well-known example being pathogenic BRCA1/2 gene variants (23). Lower cumulative lifetime risks of breast cancer followed from analyses that excluded index patients while including first-degree relatives.

In conclusion, in this nationwide study which allowed for the inclusion of $S D H B$ germline mutation carriers identified in the Netherlands, we found a lower rate of metastatic disease and a relatively high number of HNPGLs compared with previous reports of referralbased cohorts. This is most probably not a regional phenomenon but the result of the more comprehensive inclusion of unaffected mutation carriers, underlining the importance of including both disease-affected and unaffected individuals in studies that assess the phenotype of germline mutations. It furthermore highlights the importance of thorough tumor screening protocols that include radiology of the head and neck region in $S D H B$ mutation carriers.

\section{Declaration of interest}

The authors declare that there is no conflict of interest that could be perceived as prejudicing the impartiality of this study.

\section{Funding}

This research did not receive any specific grant from any funding agency in the public, commercial or not-for-profit sector.

\section{Author contribution statement}

Nicolasine D Niemeijer helped in study design, data collection, data analysis and preparation of the manuscript. Johannes A Rijken helped in study design, data collection and preparation of the manuscript. Karin Eijkelenkamp, Anouk N A van der Horst-Schrivers and Michiel Kerstens helped in data collection and editing of the manuscript. Carli M J Tops and Anouk van Berkel helped in data collection. Henri J L M Timmers helped in data collection and editing of the manuscript. Henricus P M Kunst, C René Leemans, Peter H Bisschop, Koen M A Dreijerink, Marieke F van Dooren and Jean-Pierre Bayley helped in data collection. Alberto M Pereira helped in data analysis and preparation of the manuscript. Jeroen $C$ Jansen helped in data collection and preparation of the manuscript. Frederik J Hes and Erik $\mathrm{F}$ Hensen helped in study design, data collection and preparation of the manuscript. Eleonora P M Corssmit helped in study design, data collection, data analysis and preparation of the manuscript.

\section{References}

1 De Lellis RA, Lloyd RV, Heitz PU, Eng C et al. World Health Organization classification of tumours, Vol 8. Pathology and Genetics of Tumours of Endocrine Organs, pp 238-242. Lyon, France: IARC Press, 2004

2 Gill AJ. Succinate dehydrogenase (SDH) and mitochondrial driven neoplasia. Pathology 201244 285-292. (doi:10.1097/ PAT.0b013e3283539932)

3 Fishbein L \& Nathanson KL. Pheochromocytoma and paraganglioma: understanding the complexities of the genetic background. Cancer Genetics 2012205 1-11. (doi:10.1016/j.cancergen.2012.01.009)

4 Gimenez-Roqueplo AP, Dahia PL \& Robledo M. An update on the genetics of paraganglioma, pheochromocytoma, and associated hereditary syndromes. Hormone and Metabolic Research 201244 328-333. (doi:10.1055/s-0031-1301302)

5 Benn DE, Gimenez-Roqueplo AP, Reilly JR, Bertherat J, Burgess J, Byth K, Croxson M, Dahia PL, Elston M, Gimm O et al. Clinical presentation and penetrance of pheochromocytoma/paraganglioma syndromes. Journal of Clinical Endocrinology and Metabolism 200691 827-836. (doi:10.1210/jc.2005-1862)

6 Neumann HP, Pawlu C, Peczkowska M, Bausch B, McWhinney SR, Muresan M, Buchta M, Franke G, Klisch J, Bley TA et al. Distinct clinical features of paraganglioma syndromes associated with SDHB and SDHD gene mutations. Journal of the American Medical Association 2004292 943-951. (doi:10.1001/jama.292.8.943)

7 Timmers HJ, Kozupa A, Eisenhofer G, Raygada M, Adams KT, Solis D, Lenders JW \& Pacak K. Clinical presentations, biochemical phenotypes, and genotype-phenotype correlations in patients with succinate dehydrogenase subunit B-associated pheochromocytomas and paragangliomas. Journal of Clinical Endocrinology and Metabolism 200792 779-786. (doi:10.1210/jc.2006-2315)

8 Srirangalingam U, Walker L, Khoo B, MacDonald F, Gardner D, Wilkin TJ, Skelly RH, George E, Spooner D, Monson JP et al. Clinical manifestations of familial paraganglioma and phaeochromocytomas in succinate dehydrogenase B (SDH-B) gene mutation carriers. Clinical Endocrinology 200869 587-596. (doi:10.1111/j.13652265.2008.03274.x)

9 Amar L, Bertherat J, Baudin E, Ajzenberg C, Bressac-de Paillerets B, Chabre O, Chamontin B, Delemer B, Giraud S, Murat A et al. Genetic testing in pheochromocytoma or functional paraganglioma. Journal of Clinical Oncology 200523 8812-8818. (doi:10.1200/ JCO.2005.03.1484)

10 van Hulsteijn LT, Dekkers OM, Hes FJ, Smit JW \& Corssmit EP. Risk of malignant paraganglioma in SDHB-mutation and SDHD-mutation carriers: a systematic review and meta-analysis. Journal of Medical Genetics 201249 768-776. (doi:10.1136/ jmedgenet-2012-101192)

11 Niemeijer ND, Papathomas TG, Korpershoek E, de Krijger RR, Oudijk L, Morreau H, Bayley JP, Hes FJ, Jansen JC, Dinjens WN et al. Succinate dehydrogenase (SDH)-deficient pancreatic neuroendocrine tumor expands the SDH-related tumor spectrum. Journal of Clinical 
Endocrinology and Metabolism 2015100 E1386-E1393. (doi:10.1210/ jc.2015-2689)

12 Bayley JP, Grimbergen AE, van Bunderen PA, van der Wielen M, Kunst HP, Lenders JW, Jansen JC, Dullaart RP, Devilee P, Corssmit EP et al. The first Dutch SDHB founder deletion in paragangliomapheochromocytoma patients. BMC Medical Genetics 20091034. (doi:10.1186/1471-2350-10-34)

13 Hensen EF, van Duinen N, Jansen JC, Corssmit EP, Tops CM, Romijn JA, Vriends AH, van der Mey AG, Cornelisse CJ, Devilee P et al. High prevalence of founder mutations of the succinate dehydrogenase genes in the Netherlands. Clinical Genetics 201281 284-288. (doi:10.1111/j.1399-0004.2011.01653.x)

14 van Hulsteijn LT, Niemeijer ND, Hes FJ, Bayley JP, Tops CM, Jansen JC \& Corssmit EP. Phenotype of SDHB mutation carriers in the Netherlands. Familial Cancer 201413 651-657. (doi:10.1007/s10689014-9738-z)

15 Plon SE, Eccles DM, Easton D, Foulkes WD, Genuardi M, Greenblatt MS, Hogervorst FB, Hoogerbrugge N, Spurdle AB \& Tavtigian SV. Sequence variant classification and reporting: recommendations for improving the interpretation of cancer susceptibility genetic test results. Human Mutation 200829 1282-1291. (doi:10.1002/ humu.20880)

16 Gill AJ, Hes O, Papathomas T, Sedivcova M, Tan PH, Agaimy A, Andresen PA, Kedziora A, Clarkson A, Toon CW et al. Succinate dehydrogenase (SDH)-deficient renal carcinoma: a morphologically distinct entity: a clinicopathologic series of 36 tumors from 27 patients. American Journal of Surgical Pathology 201438 1588-1602.

17 Papathomas TG, Gaal J, Corssmit EP, Oudijk L, Korpershoek E, Heimdal K, Bayley JP, Morreau H, van Dooren M, Papaspyrou K et al. Non-pheochromocytoma (PCC)/paraganglioma (PGL) tumors in patients with succinate dehydrogenase-related PCC-PGL syndromes: a clinicopathological and molecular analysis. European Journal of Endocrinology 2014170 1-12. (doi:10.1530/EJE-13-0623)

18 Ricketts CJ, Forman JR, Rattenberry E, Bradshaw N, Lalloo F, Izatt L, Cole TR, Armstrong R, Kumar VK, Morrison PJ et al. Tumor risks and genotype-phenotype-proteotype analysis in 358 patients with germline mutations in SDHB and SDHD. Human Mutation 201031 41-51. (doi:10.1002/humu.21136)

19 Gimenez-Roqueplo AP, Caumont-Prim A, Houzard C, Hignette C, Hernigou A, Halimi P, Niccoli P, Leboulleux S, Amar L, BorsonChazot $\mathrm{F}$ et al. Imaging work-up for screening of paraganglioma and pheochromocytoma in SDHx mutation carriers: a multicenter prospective study from the PGL.EVA Investigators. Journal of Clinical Endocrinology and Metabolism 201398 E162-E173. (doi:10.1210/ jc.2012-2975)

20 Benn DE, Robinson BG \& Clifton-Bligh RJ. 15 Years of paraganglioma: clinical manifestations of paraganglioma syndromes types 1-5. Endocrine-Related Cancer 201522 T91-T103. (doi:10.1530/ERC-150268)

21 Welander J, Soderkvist P \& Gimm O. Genetics and clinical characteristics of hereditary pheochromocytomas and paragangliomas. Endocrine-Related Cancer 201118 R253-R276. (doi:10.1530/ERC-11-0170)

22 Astrom K, Cohen JE, Willett-Brozick JE, Aston CE \& Baysal BE. Altitude is a phenotypic modifier in hereditary paraganglioma type 1: evidence for an oxygen-sensing defect. Human Genetics 2003113 228-237. (doi:10.1007/s00439-003-0969-6)

23 Vos JR, Hsu L, Brohet RM, Mourits MJ, de Vries J, Malone KE, Oosterwijk JC \& de Bock GH. Bias correction methods explain much of the variation seen in breast cancer risks of BRCA1/2 mutation carriers. Journal of Clinical Oncology 201533 2553-2562. (doi:10.1200/ JCO.2014.59.0463)

Received 28 January 2017

Revised version received 24 April 2017

Accepted 10 May 2017 